\title{
Standard vs. Upcycled Fashion Design and Production
}

\section{Sara Li-Chou Han, Priscilla YL Chan, Praburaj Venkatraman, Phoebe Apeagyei, Tracy Cassidy \& David J Tyler,}

Profile - This team of academics from Manchester Metropolitan University (MMU) and the University of Huddersfield consists of:

- Sara Li Chou Han - Research Associate and PhD Candidate in Circular Economy Fashion Strategies at MMU.

- Dr. Priscilla YL Chan - Senior Lecturer in International Fashion Business at MMU.

- Dr. Praburaj Venkatraman - Senior Lecturer in Textile Technology at MMU.

- Dr. Phoebe Apeagyei - Senior Lecturer in Fashion Technology and Anthropometrics and Apparel PhD Research Degrees Coordinator at MMU.

- Dr. Tracy Diane Cassidy - Reader in Fashion and Textiles at the University of Huddersfield.

- Dr. David J Tyler - Senior Research Academic and Reader at MMU.

Research interests across the team include: sustainable design techniques, waste management strategy, post-consumer textiles, branding, consumer perceptions, sustainability, textile quality control, high performance materials, outdoor sports apparel product development, supply chain dynamics, 3D body scanning technology, anthropometrics, body cathexis, body image, sizing, costume simulation, pattern cutting, color forecasting, vintage clothing and price psychology.

Sara L-C. Han, Priscilla Y. L. Chan, Praburaj Venkatraman, Phoebe Apeagyei, Tracy Cassidy \& David J. Tyler. (January 2017) Standard vs. Upcycled Fashion Design and Production, Fashion Practice, 9(1), 69-94.

Print ISSN: 1756-9370.

doi: 10.1080/17569370.2016.1227146 


\section{Abstract}

Value streams for collected post-consumer textiles continue be analyzed within the global challenge to develop and employ commercially viable, yet ethical and sustainable strategies within the fashion industry. Upcycling is an existing strategy applicable to fashion production, with discarded materials used to design and create higher value products, keeping them in productive use for longer. A number of very small, niche upcycling enterprises have emerged in the UK. These brands have succeeded in creating stylistically relevant and commercially successful fashion styles utilizing waste textile materials. The advantages of scaling these enterprises up are not only environmental, but also economic and social, thereby creating a sustainable and innovative business model for UK led fashion production.

Due to high levels of three key metrics of carbon, water and waste, UK government agency WRAP (Waste \& Resources Action Programme) has identified textile products as priority materials for reuse and recycling. Upcycling enables a sustainable design option for reuse techniques to be employed for greatest economic and environmental benefit, in which used clothing and textiles are sourced for the production of newly designed fashion products. This paper identifies the key differences between standard fashion design and production processes and upcycled fashion design and production processes, in order to aid the development of large-scale fashion upcycling in the UK, and contribute to a circular economy.

\section{Key words:}

Upcycling; Textile Waste; Design; Production; Sustainability; Fashion; Retail

\section{Introduction}

Our study is concerned with the production of upcycled womenswear garments within the range of style, quality and price of UK high street fashion, which is affordable to the majority of fashion consumers; comparing like with like, where possible. In order to achieve this a number of upcycled fashion brands and a mainstream fashion brand were selected, having similar quality, affordability and stylistic relevance. The main design and production concerns each faced were then evaluated through semi-structured interviews and design process documentation.

These factors were used to create a conceptual model for the design and large-scale manufacturing of upcycled fashion products, including effective marketing strategies. This model was then critically and comparatively analyzed in relation to current design and manufacturing processes and forms a 
basis for further research and exploration. The practical implications of this research include the development of a new UK based sustainable design and production approach, which directly tackles the issue of textile waste and offers scope for further employment and training within the industry. Social implications include recommendations on how best to engage with the public on environmental issues in the apparel industry, and the wider effects of these issues.

\section{Background}

The UK alone discarded approximately 2.35 million tons of clothing and textile waste in 2006 (Allwood et al. 2006: 16). Fletcher (2008: 98) calculated that this equates to around $40 \mathrm{~kg}$ of textile waste per person in the UK, of which only $13 \%$ is sent to material recovery, with $13 \%$ sent to incineration. The remaining $74 \%$ (around $30 \mathrm{~kg}$ per person) is sent to landfill, where textiles contribute to the negative environmental impact of these sites, such as the production of methane emissions and pollution of groundwater through toxic leachate.

Once collected, post-consumer textiles are processed and sorted; an activity requiring skilled workers to identify and separate wearable from un-wearable textile grades, ready for recycling. In a study by Farrant et al. (2010: 727) the route of donated second hand clothing is defined hierarchically, with the best pieces being resold in western markets, lower quality items exported to Eastern Europe and Sub-Saharan Africa, and the least good recycled, incinerated or thrown into landfill. The countries of Sub-Saharan Africa received close to 30\% of world exports of SHC in 2001. These imports carried a total value of $\$ 405$ million, up from $\$ 117$ million in 1990 (Hansen 2004: 4). The textile collection industry is however in a state of flux, as quality is reducing and volumes are increasing, creating financial imbalance.

As little as $3 \%$ of collected textiles are resold in the UK as premium or vintage clothing, which can have a resale value much closer to that of new clothing. Around $75 \%$ are exported for reuse overseas, with 18\% sold as recycling grades (Bartlett, McGill, and Willis 2013: 95). Morley, McGill, and Bartlett (2009: 4) recommend that as traditional markets in the UK are declining, development, such as innovation in new markets, products and processes will help to stabilize this decline and also create new markets for textile reuse.

The concept of upcycling presents an opportunity for designers to lead the way, in utilizing the many tons of textile waste produced to satisfy the constant demand for new fashion, while technological developments advance towards more sustainable methods of production. Consumer appetite for newness has led to the current situation of over-consumption and over-production, resulting in waste, pollution and harmful emissions, as well as a depletion and exploitation of natural resources. 
High volumes of textile waste have been viewed as the end of the line for those discarded garments; however, the fashion industry could be utilizing this resource to create well-designed and sustainably sourced upcycled clothing.

The current economy can be described as a linear system, in which products are made and then discarded, often into landfills, causing environmental problems such as carbon emissions and toxic pollution. Research has shown that discarded garments still have a significant portion of their potential useful life embodied at the time of their disposal. In rectification, upcycling seeks to optimize the end-of-life processes of an otherwise inefficient industrial system while we transition towards zero waste future systems. Creating a circular economy for the UK fashion and textiles industry, in which waste textiles are cycled back to become source materials for new garments, would provide environmental savings.

The fashion upcycling process (also termed refashioning or remanufacturing) has been defined by academics and practitioners as an upward reprocessing of waste, recovering intrinsic value through recycling, recutting, refashioning and closing the loop of the manufacturing system (Dunn 2008: 6; Fraser 2009: 16; Aus 2011: 41; Dadigamuwage 2012: 58). In this way, once sourcing from pre- and post-consumer waste textiles has occurred, the upcycled fashion design and production supply chain bears intrinsic similarities to the standard fashion design and production supply chain, with stages of manufacture, distribution, wholesale, retail, and purchase by consumers.

Despite this, investigation into current upcycling practice reveals significant differences between these seemingly similar yet differing processes, which should be taken into account when considering scaling up the upcycling processes involved for the mass market. In the UK, there are currently a number of small, independent upcycling designers, who are successfully making use of waste textiles, a largely under-utilized source of supply for the fashion industry. These upcycling businesses are often small artisan led enterprises, and are producers of niche products that rely on local sales and customers (Payne 2011: 11). Post-consumer waste is often used as the source material and although there has been some success translating the products they make to high street retail, the greatest success in translating upcycling to main stream retail would appear to be through the use of post-industrial (or pre-consumer) waste, as these textiles provide more consistent quality and reliable supply as source materials .

In utilizing key research into the main differences and similarities between standard and upcycled production, plus emphasizing design led production, it may be feasible to develop this niche enterprise into a large-scale industry with increasingly significant environmental savings. The hypothesis is made that as upcycling designers source from waste streams and do not place purchase orders with fabric suppliers, the design and production process for upcycling must be 
significantly different from the design process for original ready-to-wear garments. An understanding of the key differences between these two processes may allow successful and wholly beneficial integration of sustainable practices into large-scale fashion manufacturing and develop work by Cassidy and Han (2012:157) to conceptually model the upcycling process.

To facilitate comparative evaluation of the main design and production processes utilized by upcycled womenswear production in the UK, standard fashion design and manufacturing processes from literature were investigated, again developing initial work by Cassidy and Han (2012:159), comparing processes. These methods are highly iterative and at times non-linear, however for the purposes of comparison they have been summarized into one process model, which in turn has been streamlined and used for comparing standard fashion processes to upcycling. In each of the design models examined from literature, the process is often initiated with a brief, which outlines the design task or problem (Burke 2008: 110). This is then followed by research of the market and of the creative aspects of the range to be produced. The design process or synthesis phase is where the problems are solved and possible solutions ideated. This is followed by the making of sample products, which form the basis for promotion and marketing, before the products are manufactured and distributed to retailers, ready for consumers. Based on processes outlined by McKelvey and Munslow (2003: 3); Jenkyn Jones (2005: 128); Burke (2008: 110); Matharu (2010: 88) and Armstrong and LeHew (2011: 37) a summarized design and production process model has been created and is shown in Figure 1. 


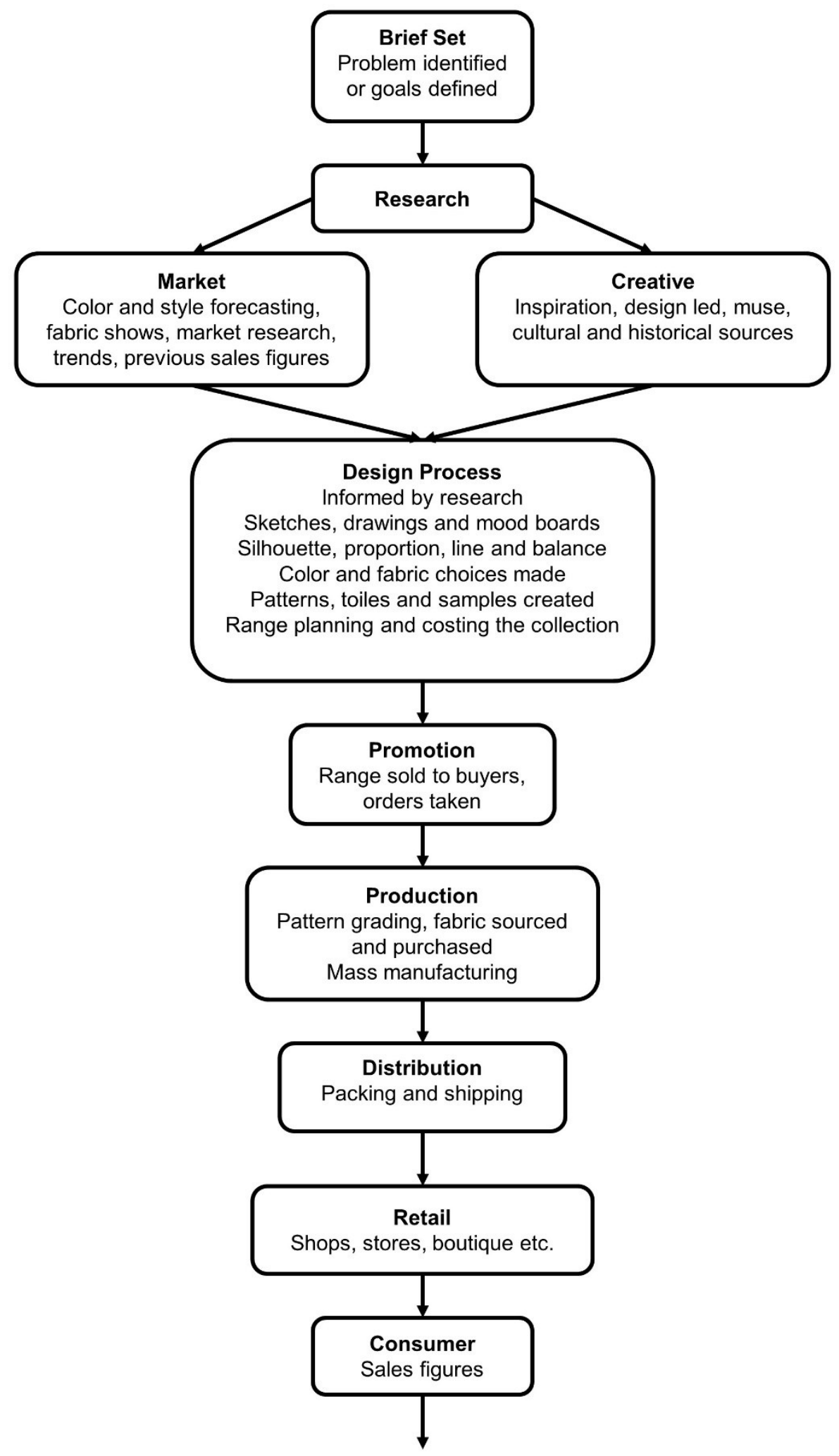

Figure 1. The Summarized Standard Design and Production Process Model

(Adapted from: McKelvey and Munslow (2003: 3); Jenkyn Jones (2005: 128); Burke (2008: 110); Matharu (2010: 88) and Armstrong and LeHew (2011: 37)) 


\section{Methodology}

In this qualitative study, a constructionist approach to research was taken, which implies that social phenomena, such as the emerging fashion upcycling industry within the UK and its related aspects, are produced through the social interaction of the groups and individuals involved, and are in a constant state of revision (Bryman 2008: 19). This approach has enabled us to investigate the ways in which individuals and groups participate in the construction of an upcycling process as part of their practice. Qualitative research methods were used as the study chiefly deals with participants' recollections of their own practice. An inductive approach was used to develop insights in order to propose hypotheses and shape theories derived from the qualitative data collected in accordance with Bryman (2008: 11).

The primary research conducted in the study provided new information and enabled an understanding of specific considerations relating to design, research, production and consumer related issues faced by upcycled women's wear producers in the UK. Several standard design and manufacturing processes were also evaluated from existing literature, as part of a comparative analysis exercise with the upcycling processes outlined in the research. Processes may be investigated in real time through participant observation, through retrospective interviewing or by constructing a processual account through the examination of documents (Bryman 2012: 403). In this study processes were documented through the observation of professional upcycling practice, semi-structured interviews with designers, documentation of the first authors own upcycling practice and the examination of literature relating to the fashion design and production process.

The summarized thematic analysis of the six interviews and first author's process documentation identifies points of difference and similarity in the processes described by the designers. These summaries were modeled into flow charts, described by Giaglis (2001: 215) as a simple, graphic means of communication, intended to support narrative descriptions of processes when the latter become complicated and difficult to follow.

\section{Sample Selection}

The upcycling brands involved in this study represent the mixed range of UK fashion upcycling, from higher profile labels that show regularly on and off schedule at London Fashion week, to smaller labels, producing a limited collection for a loyal customer base, mainly reached through social media. The high street label chosen is a brand that has expressed an active corporate social responsibility policy as a member of the Ethical Trading Initiative. 
Brand 1. A high profile upcycling brand, known for body conscious styles. This brand stocks a number of specialist boutiques and has exhibited at Estethica at London Fashion Week on a number of occasions and collaborated with larger retailers. Based in London, UK with production in the UK and Bulgaria.

Brand 2. A high profile upcycling brand, known for pioneering collaborations between educational institutions and upcycling innovators. Heavily involved in Estethica at London Fashion Week each year and known for collaborations with large retailers. Based in London, UK with production in Italy.

Brand 3. A well-established Micro SME upcycling brand based in Bristol, UK with a background in academic research informing sourcing decisions. This brand manufactures and produces through a network of UK makers and artisans and stocks a number of specialist boutiques internationally.

Brand 4. A small independent UK upcycling brand based in Manchester. This brand has a wellestablished customer base and stocks specialist boutiques in the UK and in Europe. All materials sourced are entirely post-consumer. UK based production.

Brand 5. A small independent UK upcycling brand based in Brighton, UK specializing in customized tailored jackets. A niche brand with a small, but well-established following including some wellknown musicians in the UK and specialist boutiques internationally.

Brand 6. The first author's own independent sole trader brand, creating one of upcycled denim wear pieces, based in Manchester, UK. The brand utilizes discarded second hand denims, diverting to create designer-maker fashion products which are sold at a specialist boutique in Manchester, and through one-off events.

Brand 7. A medium sized UK high street brand specializing in active lifestyle wear that uses a standard design and production model, sourcing new materials. A member of the Ethical Trading Initiative with over 200 physical retail units in the UK and Ireland. Overseas production is managed by the brand's India satellite office.

\subsection{Interview Analysis}

Data gathered through interviews with upcycling designers and the high street label designer was analyzed using thematic analysis, allowed themes to emerge from the data through the technique of coding. Codes were used to separate, compile and organize the data and to represent sets of themes and concepts which were illustrative of the key points and areas for consideration (Bryman, 2012: 578). In this way data was treated as potential indicators of concepts or classes of events or behaviors. From these indicators, concepts could be generated, which were used to build theories. Qualitative data analysis software NVIVO was used to facilitate thematic analysis of the interview 
data by providing an interface with which to categorizing the themes and concepts. (Bryman, 2012: $581)$.

\section{Standard vs. Upcycled Fashion Design and Production}

\subsection{Comparative Results Table}

Interview findings from all designers and brands interviewed were summarized and tabulated below in Table 1, to highlight points of difference and similarity.

Recurring themes of design brief, sourcing, research, design, promotion, production, retail and consumers were present throughout all the interviews, and form the basis for the summary. 
Table 1(a). Comparative Results of the Thematic Analysis

\begin{tabular}{|c|c|c|}
\hline & $\begin{array}{l}\text { Upcycled Fashion Designers } \\
\text { (Brands, 1, 2, 3, 4, } 5 \text { \& 6) }\end{array}$ & $\begin{array}{l}\text { Mainstream Fashion Designer } \\
\text { (Brand 7) }\end{array}$ \\
\hline 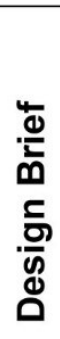 & $\begin{array}{l}\text { - Utilizing waste as a source material. } \\
\text { - Reducing production impact on the } \\
\text { environment. } \\
\text { - Sourcing materials locally. } \\
\text { - Supporting local communities. }\end{array}$ & $\begin{array}{l}\text { - } \quad \text { Trend led. } \\
\text { - } \quad \text { No sustainability ethos expressed. }\end{array}$ \\
\hline 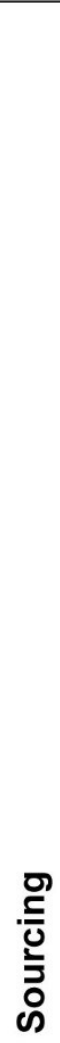 & $\begin{array}{l}\text { - All sourcing directly handled by the designers. } \\
\text { - Post-consumer textiles (Brands } 1,3,4,5 \& 6 \text { ). } \\
\text { (Textile collectors, car boot sales, jumble sales, } \\
\text { charity shops, eBay, vintage clothing dealers, } \\
\text { clothes swaps and house clearances.) } \\
\text { - Post-industrial textiles (Brands } 1,2 \& 3 \text { ). } \\
\text { (Clothing manufacturers, textile mills, knit and yarn } \\
\text { manufacturers - over orders, unsold stock, faulty } \\
\text { dye jobs and goods, returned and over produced } \\
\text { orders, test strips, wash test batches, dead stock } \\
\text { and off-cuts.) } \\
\text { - Main issues: consistency and supply, fast } \\
\text { fashion leading to lower quality source } \\
\text { materials, sorting of the source materials and } \\
\text { obtaining the correct quantity of source } \\
\text { materials. }\end{array}$ & $\begin{array}{l}\text { - Trade shows, suppliers, and } \\
\text { factories. } \\
\text { - Initial choices made by designer, } \\
\text { but bulk sourcing handled further } \\
\text { down the supply chain. }\end{array}$ \\
\hline 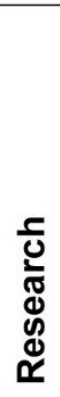 & $\begin{array}{l}\text { - Sourcing and design based, mood boards, } \\
\text { creative inspiration. } \\
\text { - Availability of waste textiles, quantity, quality, } \\
\text { location. } \\
\text { - Consumer engagement at community } \\
\text { workshops. }\end{array}$ & $\begin{array}{l}\text { Mood boards, color palettes, key } \\
\text { trends, lifestyle themes, plus yarn } \\
\text { and fabric samples. }\end{array}$ \\
\hline
\end{tabular}


Table 1(b). Comparative Results of the Thematic Analysis

\begin{tabular}{|c|c|c|}
\hline & $\begin{array}{l}\text { Upcycled Fashion Designers } \\
\text { (Brands, 1, 2, 3, 4, } 5 \& 6 \text { ) }\end{array}$ & $\begin{array}{l}\text { Mainstream Fashion Designer } \\
\text { (Brand 7) }\end{array}$ \\
\hline 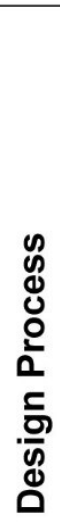 & $\begin{array}{l}\text { - Drawings, mood boards and toiles. } \\
\text { Brands 1, } 2 \text { \& 3: in house teams at each } \\
\text { organization design, pattern-cut and make } \\
\text { samples of initial designs and ranges. } \\
\text { - Flexible design and 'patchwork' pattern cutting } \\
\text { techniques allow for fabric substitutions to be } \\
\text { made, depending on availability. (See Figure } 2 \\
\text { (a \& b). }\end{array}$ & $\begin{array}{l}\text { - Drawing designs, choosing print } \\
\text { and fabric options, setting technical } \\
\text { specifications and overseeing } \\
\text { sample preparation remotely. } \\
\text { - Seasonal collections designed as a } \\
\text { team. }\end{array}$ \\
\hline & Patchwork' pattern cutting techniques usec & Brand 2 (front (a) and back (b)) \\
\hline 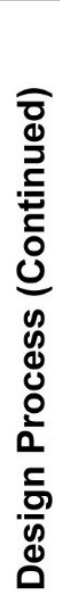 & $\begin{array}{l}\text { - Non-seasonal slow design process by collection } \\
\text { as produced, not by season. } \\
\text { Design and production stages combined for } \\
\text { Brands } 5 \text { \& } 6 \text { due to one off and customized } \\
\text { nature of design. }\end{array}$ & \\
\hline
\end{tabular}


Table 1(c). Comparative Results of the Thematic Analysis

\begin{tabular}{|c|c|c|}
\hline & $\begin{array}{l}\text { Upcycled Fashion Designers } \\
\text { (Brands, 1, 2, 3, 4, } 5 \text { \& 6) }\end{array}$ & $\begin{array}{l}\text { Mainstream Fashion Designer } \\
\text { (Brand 7) }\end{array}$ \\
\hline & $\begin{array}{l}\text { - Upcycling designers directly involved in this } \\
\text { stage: } \\
\text { - Social media: Facebook, Twitter, Pinterest and } \\
\text { blogs } \\
\text { - Brand website, clear brand identity, logo and } \\
\text { signature style of clothing. } \\
\text { - Trade shows and fashion weeks. Estethica, } \\
\text { London Edge, The Clothes Show Live, Ethical } \\
\text { Fashion Show (Berlin), The Good Fashion } \\
\text { Show. } \\
\text { CSR Consultancy for larger mainstream brands, } \\
\text { leading to national press coverage. } \\
\text { Public engagement directly linked to the brands } \\
\text { sustainability ethos: lectures, public speaking, } \\
\text { education workshops, and community events. }\end{array}$ & $\begin{array}{l}\text { - The designers at Brand } 7 \text { are not } \\
\text { involved in the process of } \\
\text { promotion. }\end{array}$ \\
\hline 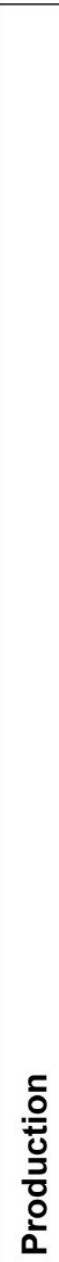 & $\begin{array}{l}\text { - Outsourced for larger wholesale orders. } \\
\text { Brand } 1 \text { has set up an upcycling factory in } \\
\text { Bulgaria. } \\
\text { Brand } 2 \text { utilizes a co-operative in a garment } \\
\text { making region of Italy, employing disadvantaged } \\
\text { individuals. } \\
\text { - Brand } 3 \text { employ an innovative modular } \\
\text { production technique of utilizing many designer- } \\
\text { makers, who either sew or make either in the } \\
\text { Brand } 3 \text { studio workroom/factory, or at home. } \\
\text { Designs by Brand } 4 \text { are made almost } \\
\text { exclusively by the sole designer-maker and } \\
\text { business owner, however for large orders extra } \\
\text { seamstresses are employed. } \\
\text { The designer-maker team at Brand } 5 \text { is in } \\
\text { constant production to create stock for their } \\
\text { Brighton shop and to meet wholesale and } \\
\text { custom orders. } \\
\text { At Brand } 6 \text { design and production occurred } \\
\text { simultaneously and was carried out by the sole } \\
\text { designer-maker and business owner. }\end{array}$ & $\begin{array}{l}\text { - The role of the designer at Brand } 7 \\
\text { did not extend into the production } \\
\text { stages past initial sample sign off. }\end{array}$ \\
\hline
\end{tabular}


Table 1(d). Comparative Results of the Thematic Analysis

\begin{tabular}{|c|c|c|}
\hline & $\begin{array}{l}\text { Upcycled Fashion Designers } \\
\text { (Brands, 1, 2, 3, 4, } 5 \text { \& 6) }\end{array}$ & $\begin{array}{l}\text { Mainstream Fashion Designer } \\
\text { (Brand 7) }\end{array}$ \\
\hline 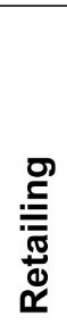 & $\begin{array}{l}\text { - Online through own websites. } \\
\text { - Wholesale orders for other boutiques and } \\
\text { websites. } \\
\text { - Brand } 5 \text { has its own retail premises in Brighton. }\end{array}$ & $\begin{array}{l}\text { Designers at Brand } 7 \text { were not } \\
\text { actively involved with retail but did } \\
\text { receive information on sales } \\
\text { figures. }\end{array}$ \\
\hline $\begin{array}{l}\frac{\omega}{2} \\
\text { है } \\
0 \\
0 \\
0 \\
0\end{array}$ & 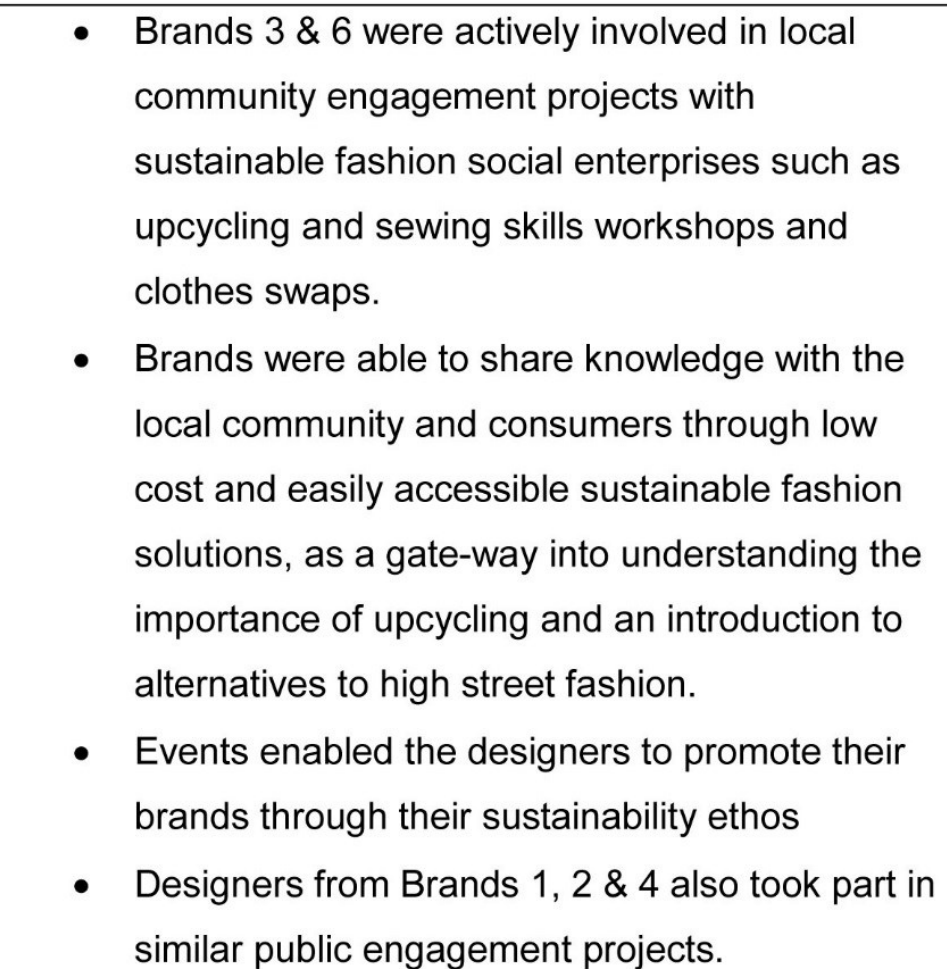 & $\begin{array}{l}\text { - As mentioned in 'Retailing', } \\
\text { designers at Brand } 7 \text { were not } \\
\text { actively involved with retail but did } \\
\text { receive information on sales } \\
\text { figures. }\end{array}$ \\
\hline
\end{tabular}



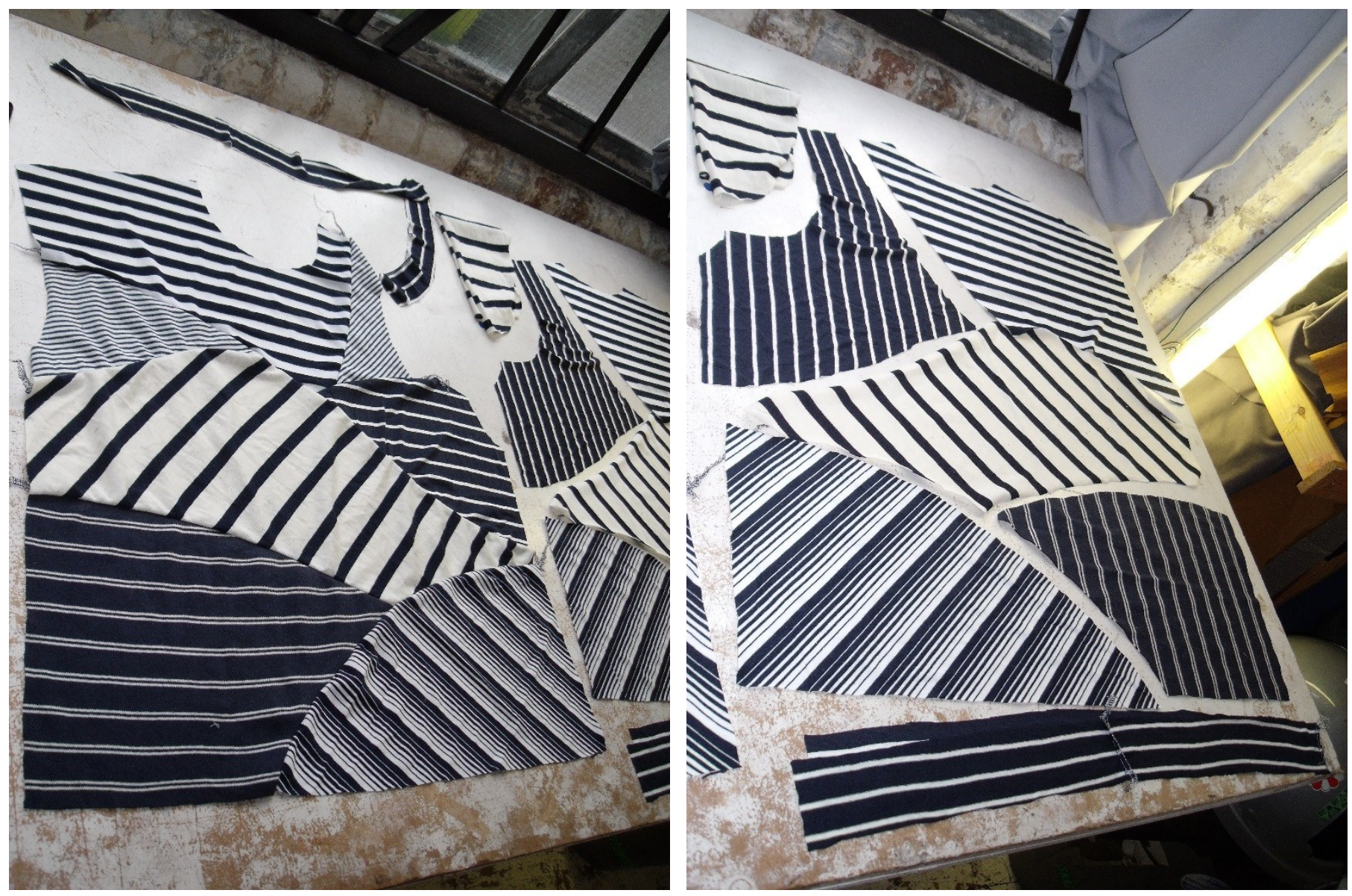

Figure 2 (a \& b). A T-Shirt in Production at Brand 2 (front (a) and back (b)) 


\subsection{Standard Fashion Design and Production}

\subsubsection{High Street Design Process}

A knitwear designer from Brand 7 was interviewed as part of the research into standard practice for comparison, and the design process within this high street fashion organization derived from these data. The process is as follows in Figure 3.

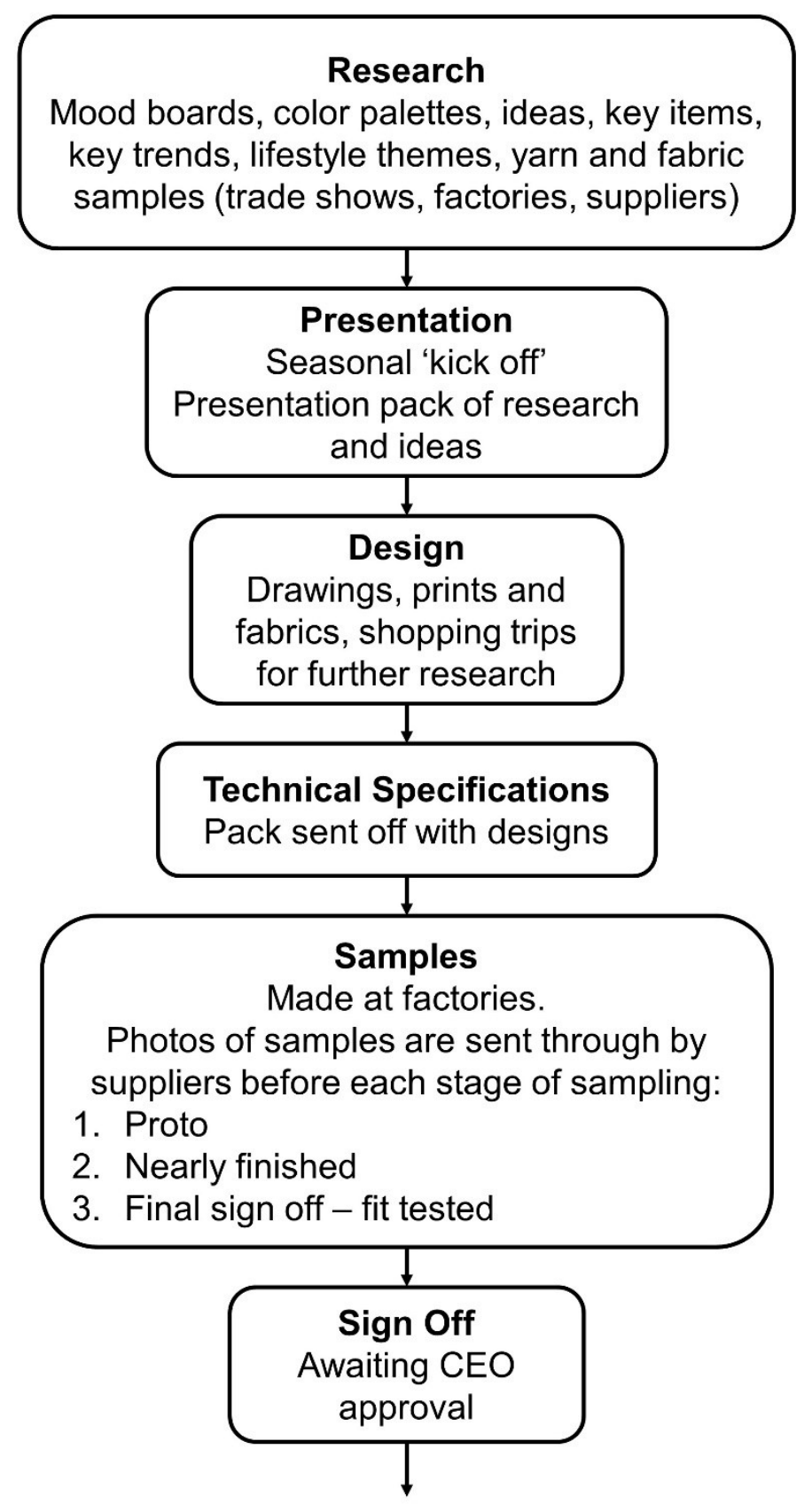

Figure 3. The High Street Design Process

The high street design process investigated for Brand 7 indicated that the designer's role at this brand had clearly defined limits of research, design and sample production, and did not extend beyond this remit. Unrestricted and trend-led yarn and fabric choices were made at trade shows, 
through suppliers and factories, with no sustainable options requested or offered. In the production and sample stages, the designer would oversee the production of a prototype sample, then a second stage, followed by a final garment. This garment was then fit tested, signed off and sealed up to be passed along to the next stage in the design and production process. This process aligns with the first stage of the summarized process, in which a brief is set, research is carried out and designs and samples are created.

\subsubsection{The Abbreviated Standard Fashion Design and Production Process Model}

From the summarized model in Figure 1, showing details of activities which occur at each stage, a further streamlined process model has been created in Figure 4 below to clearly show the main stages in standard fashion design and production, including fabric sourcing. This model will be used for the comparison with the upcycling model created from further data in the research in Figure 8. 


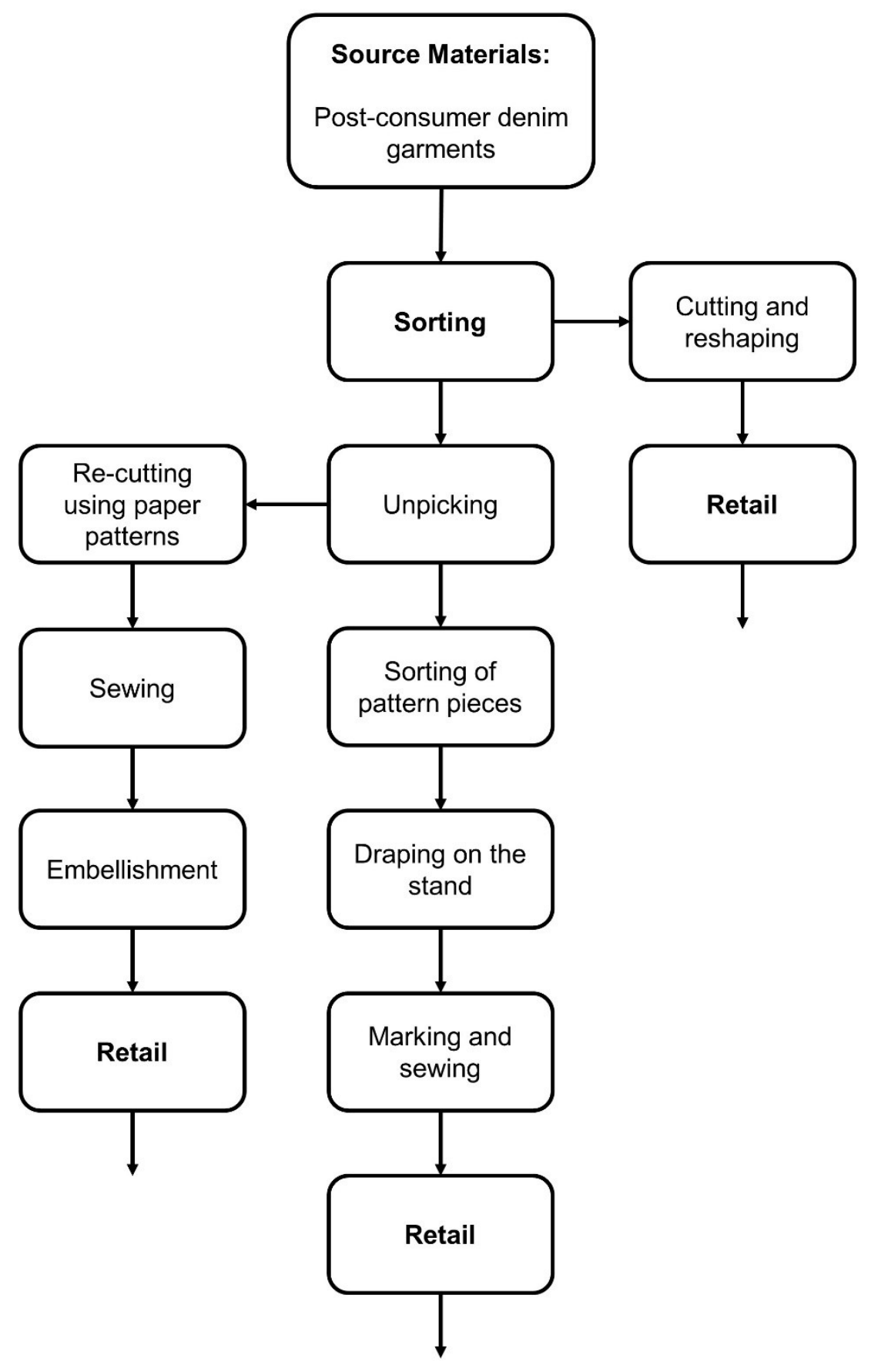

Figure 4. Abbreviated Standard Fashion Design and Production Process Model

\subsection{Upcycled Fashion Processes}

The results from the interviews and documentation of the first author's own design process were modelled in order represent and evaluate the processes used in upcycled fashion.

\subsubsection{The Upcycled Denim Wear Process}

Initially, the first author's upcycled denim wear process (Brand 6) was documented for the purposes of evaluating the main design and production processes used by upcycled women's wear production 
in the UK. From this research, an initial upcycling process model was created in Figure 5 for denim wear.

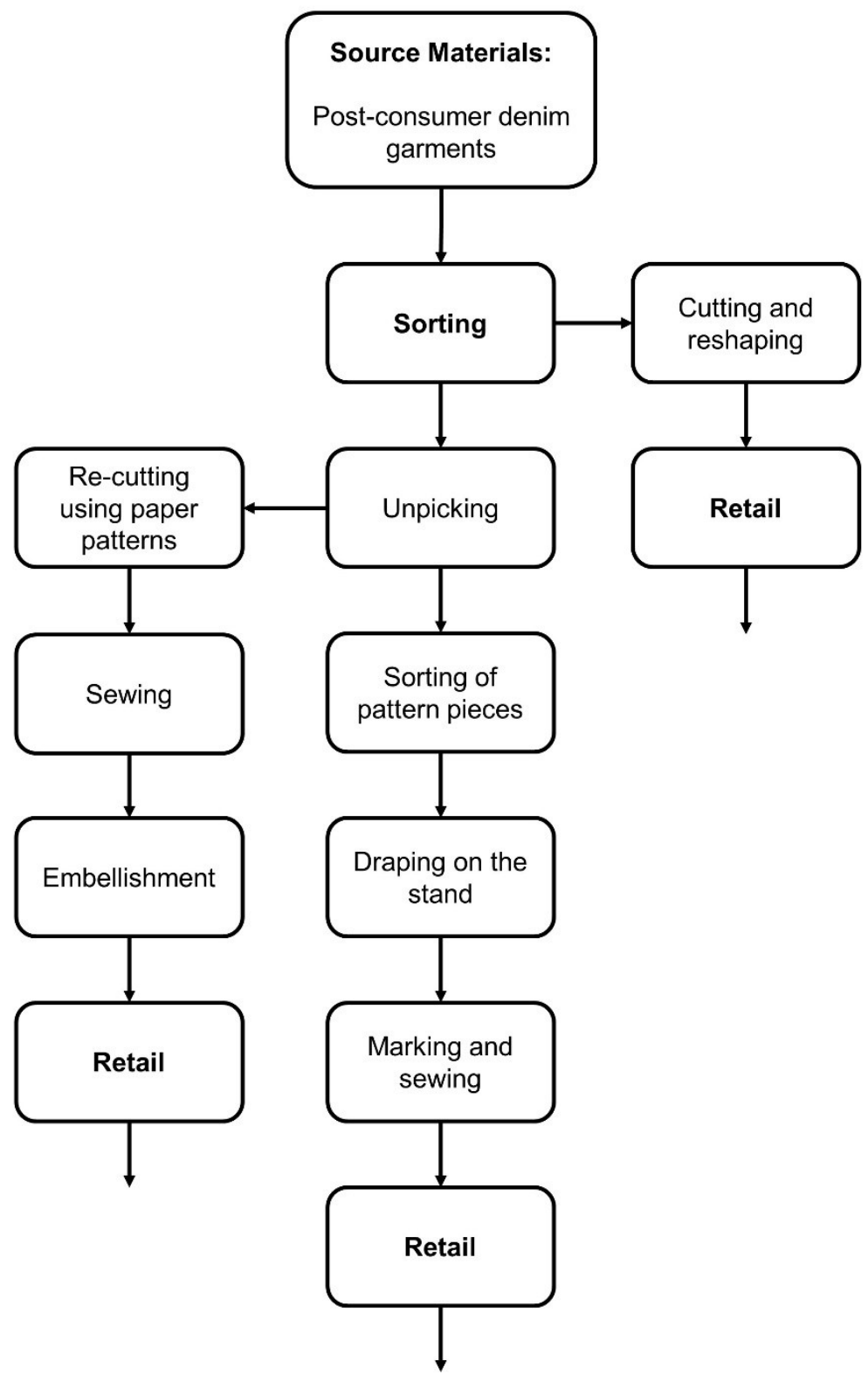

Figure 5. The Upcycled Denim Wear Process Model 


\subsubsection{The Upcycled Fashion Design and Production Process Model}

Five additional UK-based upcycling designers were then interviewed to gain insights into the processes of sourcing, design, production, retail and promotion. The results from this research were combined with those from the denim wear documentation and used to further inform and develop an upcycled fashion design process model in Figure $6(a \& b)$.

\section{Brief Set}

Reusing post-consumer and post-industrial textile waste to create a large-scale upcycled fashion collection

\section{Fabric Sourcing}

- Increased textile banks, kerbside collection and retailer take back schemes - fed into local textile collectors and recyclers.

- Post-consumer waste from local textile collectors - specific textiles in good quality and high quantity.

- Post Industrial waste from local garment manufacturers and mills fabric still on the roll, and suitable unsold garments in good quality and sufficient quantity.

\section{Research}

- Flexible initial ideas relating to trends, fabrics, colours, styles and consumer feedback and preferences, as well as creative inspiration.

- Availability of fabrics - information on colour, pattern, thickness, woven or knitted, fibre composition and production.

- Consumer feedback and preferences.

\section{Design}

- Informed by research and consumer feedback and preferences.

- Colour palette created from available source materials.

- Mood boards, sketches and design development informed by colour palette, source materials and artisan skills.

- Silhouette, proportion, line and balance.

- Textile manipulation, experimentation and draping.

- 'Patchwork' pattern cutting, toiles and sample making.

- Designs created with product specifications and flexibility in fabric choices.

- Range planning and costing of the collection.

Figure 6(a). The Upcycled Fashion Design and Production Process Model 
Promotion

- Range sold to retail buyers - wholesale orders taken.

- Social media / online / website / branding.

- Communication with consumers.

- Pattern grading.

\section{Production}

- Outsourced and centralized manufacturing used in combination emphasis on planning.

- Local independent homeworkers, seamstresses and designermakers, each assigned specific parts of the collection as piece work, to manufacture within a time limit.

- Option for production at centralized design studio, also using freelance, modular designer-maker units.

- Online-e-commerce.

\section{Retail}

- Wholesale - Shops, stores and boutiques etc.

\section{Consumers}

- Promotion through Social Media, (Facebook, Twitter, Pinterest, blogs, websites) media and celebrity, fashion magazines, endorsement, branding and style identity).

- Consumer and community engagement - clothes swaps, workshops, events and fashion shows, education on recycling and reuse, consumer involvement in the design process - focus groups, product trials, feedback and recommendations.

- Sales figures.

- Feedback and preferences contributing to the 'Research' phase.

Figure 6(b). The Upcycled Fashion Design and Production Process Model (continued) 


\subsubsection{The Abbreviated Upcycled Fashion Design and Production Process Model}

Following on from the development of the upcycled design and production process model, detailing activities which occur at each stage of the process, an abbreviated upcycling process model has been created in Figure 7, showing fabric sourcing as it occurs at the second stage in the process. Key issues in sourcing for upcycling were consistency, quality, quantity and sorting, with local sourcing of either post-consumer or post-industrial waste textile favored. Designs were created using traditional fashion design techniques of sketches, mood-boards and sample making, but techniques such as 'patchwork' pattern cutting created smaller pattern pieces to best utilize all available source materials. Seasonal designs often evolved slowly, taking consumer feedback into consideration.

Production was often outsourced to meet wholesale orders, which were essential to the financial success of each label. Several variations on modular manufacturing were employed and relied on well-planned production schedules and highly competent makers. Deconstruction was considered too time consuming, leading to a price increase for consumers, who were able to access upcycled designs through e-commerce sites and specialist boutiques. Favored promotional tools were social media and websites, allowing designers to identify themselves with distinctive branding and styling. Trade shows featured highly as effective means to gain wholesale orders, and celebrities were mentioned as editorial and headline grabbing promotional considerations.

Collaborations and consultancies with larger brands enabled designers to promote their labels though media coverage and to implement sustainable design strategies with high profile retailers. Community engagement projects and involvement with education enabled designers to raise the profile of their brands, and to facilitate public understanding of sustainability issues with the apparel industry. The sustainability ethos of each brand, which encompassed reducing consumption, diverting textiles from the waste stream and supporting local communities; was evident through every aspect of their design and production process. 


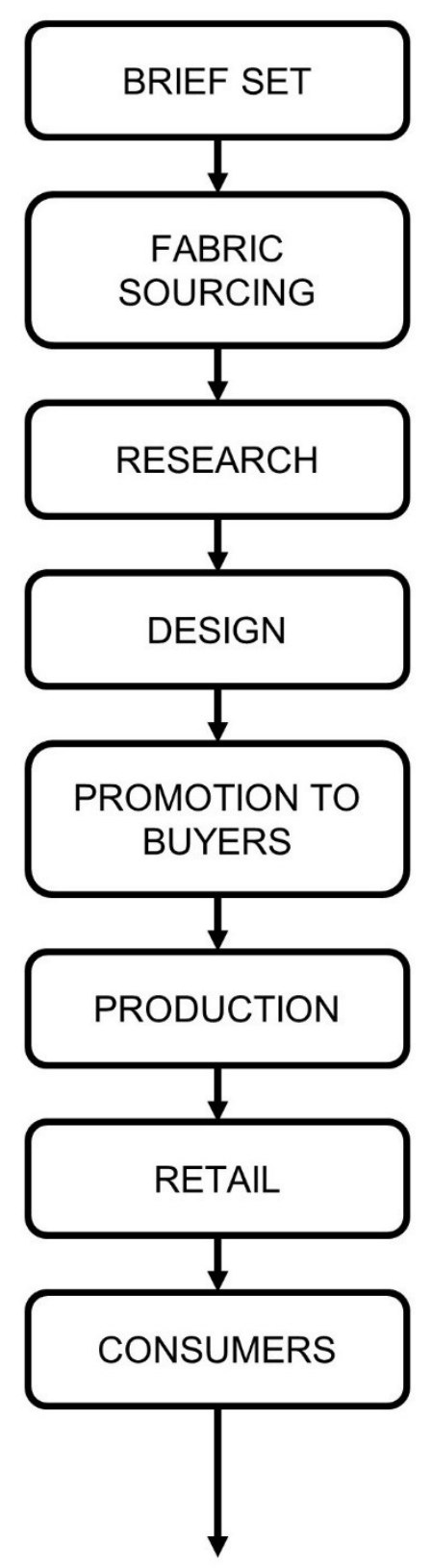

Figure 7. Abbreviated Upcycled Fashion Design and Production Process Model 


\section{Discussion and Analysis}

\subsection{Standard Design vs. Upcycling}

A comparative figure was created to identify points of divergence between standard fashion design and production, and upcycled fashion design and production processes.

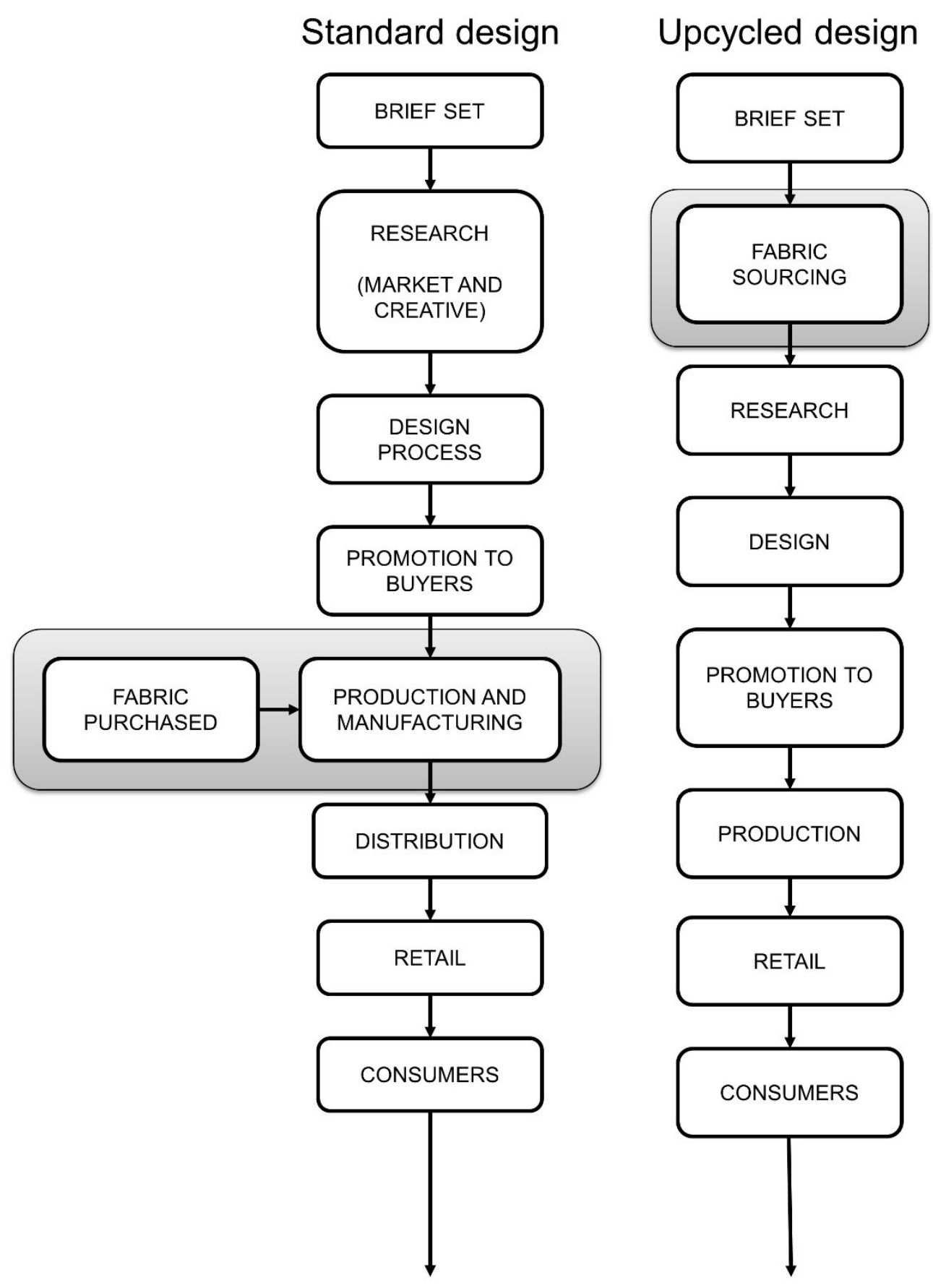

Figure 8. Standard Design vs. Upcycling 
Figure 8 shows the abbreviated standard fashion design and production model (Figure 4), presented alongside the abbreviated upcycled fashion design and production model (Figure 7) for comparative analysis. The main differences between the standard design process and upcycling process occur at the fabric sourcing stages, and during retail and consumer stages. Key differences also occur at each stage of the cycle: brief, research, design, promotion and production.

Due to the centralized role upcycling designers play within their organizations, it is possible for them to plan in sustainability strategies as parallel lines of thought alongside typical design tasks, and to consider these strategies before acting. The sustainable design strategy of 'design for waste minimization' is central to the very idea and design brief for upcycling; and results show that upcycling designers who are keen to adhere to this principle also subscribe to sustainability principles concerning localized production, support of disadvantaged workers, community engagement and education. This would indicate that these designers would be inclined to implement further sustainable design principles into their process, such as end-of-life considerations, waste minimization, design for disassembly and slower consumption (Gwilt 2011: 68); strategies which closely align with not only the ethos but also the practical process of upcycling.

\section{Design Brief}

The upcycling design brief could be seen to embody the sustainable design strategy of 'design for waste minimization' over and above all others. The main agenda of the brief is to design a fashion collection using post-consumer and post-industrial textile waste as the source materials. The results show that utilizing textile waste in designs is an integral part of the ethos and style of upcycling brands, and could be considered part of the overall design brief for each collection created. In contrast to this the brief for standard fashion design and production is linked to trends and consumer and market data.

\section{Sourcing}

Sourcing occurs at the design brief stage for upcycling with the aim of creating a fashion collection utilizing textile waste. For standard fashion design it is a pre-production stage, after wholesale orders are taken. Brand 7 and standard design literature cite sources as trade fairs, factories, suppliers. No sustainability considerations are mentioned and a reliance on the production from virgin materials is implicit. Upcycling sources are based on the availability of unused, pre-existing materials. The focus is on limiting waste and further negative production impacts. Early sourcing in upcycling does create restrictions the use of specific fabrics; however Brands 1 and 3 described how flexibility and understanding from buyers and boutiques enabled them to substitute in different, but similarly effective fabrics into designs made to order. The centralized role of the designer / directors in these instances was key to this level of understanding. 


\section{Research}

Research in fashion upcycling includes gathering data on sourcing, customers and design inspiration. It is necessary for designers to have accurate information regarding the materials that are available and in ready supply. This is achieved by maintaining up to date knowledge on availability through extensive research and a strong network of connections. In this way, design decisions can then be made on how to best utilize the set quantities of these fabric stocks in garment designs and production planning. In reference to Figure 6a, 'Research' includes the more direct involvement of customers in the design process for upcycling and is significantly different from the less personal data used in the standard research process. For upcyclers this means the direct involvement of consumers through social media to give feedback about their personal preferences. Research in the standard process, as described in Figure 1 and Figure 3, consists of mass market research, trend research, and analysis of previous sales figures.

\section{Design}

As learned from the interview with the high street designer from Brand 7, the designer's role within a large company often entails no further involvement in the fashion cycle outside of designing the garments and over-seeing the sample stages. This is further supported by evidence from Sinha (2002: 5) that designers become less manually involved with sample making as the size of the company increases, focusing more on gathering and applying market and trend data to current styles. Gwilt (2011: 63) also noted that where large-scale manufacturing occurs, the designer is involved at the research and concept stages only, and unlikely to influence any developments beyond these points. Restricted involvement outside design and sample production limits designers within standard fashion in their ability to consider, request or implement sustainability criteria. In contrast to this, designers within an upcycling organization take on a highly centralized role, in which they either directly oversee or actively perform all duties from sourcing, design and production, through to promotion and retail. This is reiterated by an upcycling designer from Brand 3, who described her role in the business, not only as a designer, but also as a curator and facilitator, overseeing production and the day-to-day running of the business.

Key design insights in the upcycling process include the technique of 'patchwork' pattern cutting, which enables the best use of set quantities of fabric. Limited supplies of key colors or prints can be used to accent designs through creative design and pattern cutting. This technique of cutting also allows greater flexibility in the substitution of fabrics into designs, meaning designers are able to make full use of less than consistent supplies of source materials, corresponding to the sustainable design strategy of 'design for waste minimization'. 


\section{Promotion}

The results from the interviews with upcycling designers demonstrated all the designers relied on wholesale orders to make up the vast majority of their sales and income. Promotion to buyers at trade shows was key to the business strategy. In gaining wholesale orders, upcycling designers were then able to produce precise amounts of stock. Often no large-scale production took place unless a wholesale order had been placed, meaning no over-production occurred; corresponding with the sustainable design strategy of 'design for slower consumption'.

The results show social media to be a key element in each upcycling brands' promotional strategy; directly involving interested customers in the brand through the opportunity to leave feedback and comments, corresponding to 'design for user participation'. A definite design identity, expressed through logos, branding and styled images gave an added advantage to these internet based methods of promotion. Effectively promoting a brand through its sustainability ethos was also done by actively engaging consumers with local community projects. The advantage of this lies in raising the profile of the brand and making eco-fashion accessible to all. Offering consumers the option of attending clothes swap events provides a 'design for end-of-life strategy' for the responsible disposal of garments. Standard and traditional fashion brands offer little in the way of services and engagement with consumers

\section{Production}

Challenges are presented in manufacturing standardized upcycled designs with consideration for flexible fabric options. In more traditional production line and factory methods, operatives use one machine to complete a singular part of the production, before passing items on to the next operative. Upcycling utilizes non-traditional methods, in which post-consumer garments are treated as flat cloth. New pattern pieces cut directly from these discarded clothes, requiring more flexibility in making up, as often minor adjustments are needed in cut or construction to create garments of a standard size. A modular system of designer-maker operatives could present a solution to this, in which individuals perform more than one process, and have access to several machines each, and the cutting table (Cassidy and Han 2012: 162). Carr and Latham (1994: 165) describe how this process would work, with each multi-skilled operator performing several operations in the sequence of construction of the garment, moving along several machines, taking a single garment through these several operations, until the garment is passed onto another operator, ready for work, and the first returns to an earlier machine to begin working on another garment.

Brands $1 \& 3$ both already use their own versions of this modular system, in which makers are responsible for specific garments or parts of garments and have access to their own complement of machines in a factory, workroom or home. Although not popular within standardized production, the 
system of modular manufacturing holds certain advantages, such as greater flexibility and autonomy, improving skill levels amongst operators and opportunity for greater job satisfaction, as operators are not placed in a fixed location, constantly performing the same repetitious task; corresponding to a strategy of 'design for social well-being'.

\section{Retail}

Key differences also occur between standard fashion design and production processes and upcycling during the retail and consumer stages. During the distribution phase of the standard fashion cycle, finished products are shipped to retailers, sold in store and sales figures recorded for the following season's merchandising (Sinha 2002: 7-8). This is also true for upcycling brands, on a much smaller scale, although it could be said that aside from the typical advertising and promotional strategies, such as editorial placements in magazines and establishing a strong internet and ecommerce presence, traditional fashion brands offer little in the way of services and engagement with consumers.

Upcycled fashion brands often demonstrate highly engaged consumer relationships, working towards overcoming the greatest challenge within the sustainable fashion industry of creating consumer demand alongside understanding of its associated products. E-commerce has emerged as the most viable and cost-effective solution for an upcycling business, with online promotion as a vital element of this strategy. Social media features heavily as a tool to reach targeted individuals, likely to have expressed prior interest in upcycling and sustainable fashion. A strong online retail presence may be bolstered by wholesale orders from specialist retailers with an understanding of upcycled products, and certain upcycling brands' own shop premises. The study concurs with previous research from Young, Jirousek, and Ashdown (2004); Thomas (2008); and Cassidy and Han (2012: 162) which indicated that these strong online retail and consumer elements are perhaps the most notable aspects of upcycling brands in creating consumer demand and understanding.

\section{Consumers}

Upcycling brands and retailers make their relationship with consumers a priority; offering events which engage consumers in the ethos and lifestyle of sustainable fashion. Clothes swaps offer a cost effective way of making sustainable fashion accessible to those who may not be able to afford to make upcycled fashion purchases impulsively, while sewing and mending workshops and events help consumers to understand the principles behind sustainable consumption, enabling the retailing of upcycled fashion products to consumers with an understanding of their ecological provenance. Upcycling brands often strengthen this relationship with consumers by including interactive social media as a key element of their promotional strategies, along with a strong online presence through their own e-commerce sites. This in turn allows the brands to fully and effectively communicate their 
ethos to their customers through their online updates and by making all their own production and social responsibility information available through their own website.

\subsection{Scope and implications}

Insights provided by the model 'Figure 8. Standard Design vs. Upcycling' include observations regarding sourcing, design, consumers and the role of the upcycling designer. Sourcing is required to occur at the beginning of the design and production schedule in the fashion upcycling process, as opposed to a pre-production stage as in standard design and production process. For multiples of consistent designs to be possible, it is necessary for designers to have accurate information about what materials are available and in ready supply, by purchasing these fabrics nearer to the start of the process (Cassidy and Han 2012: 161). In this way, design decisions can then be made on how to best utilize the set quantities of such fabric stocks in garment designs and production planning.

Key design insights include the technique of 'patchwork' pattern cutting, which enables the best use of set quantities of fabric. Limited supplies of key colors or prints can be used to accent designs through creative design and pattern cutting. Consumer insights indicate that upcycling brands offer a high level of engagement with their customers, not just through retailing fashion products, but by offering events and workshops, and communicating their ethos through social media.

Upcycling designers are central to all these operations. In implementing sourcing at an early stage in the process, and directing designs to utilize set quantities of fabric stocks, it is possible to incorporate consumer preferences for style and value. Designers are also fulfilling sustainable design strategy criteria at each stage of the process. Implications suggested by these insights include strategies for more effective sourcing in upcycling as key for making the model operational. As sourcing is crucial for creating consistent multiples of designs, a network of information for designers outlining the location, quantity, quality and composition of source materials would enable for a more effective and less time-consuming fashion upcycling process. This would also enable the implementation of large-scale upcycling as a new sustainable design approach throughout the UK fashion industry. This approach directly addresses the textile waste problem, and offers opportunities for further employment and training within the industry. New retail and business opportunities are presented within the pre-existing UK textile recycling industry and the possibility of establishing a consortium of ethical and upcycling designers within localized areas in order to best utilize resources is also presented. 


\section{Conclusions}

The findings from this study demonstrate that there are significant differences between upcycled and standard fashion and design, production and research processes. For effective upcycled fashion design to occur, specific considerations need to be made as part of the design and production schedule. Fabric sourcing must occur much earlier on in the process than in standard design and production, and pattern cutting techniques must take into account inconsistencies in supply with interchangeable fabric options. It is necessary for information on the availability of source materials to be on hand from the outset, in order to achieve consistency of design throughout production.

Design is directly informed by the available source materials, and often follows traditional techniques of drawn designs and sample making in seasonal collections. Adaptations for smaller pattern pieces, making up standardized designs, allow for greater flexibility in fabric and color combinations and substitutions. A technique or formula of 'patchwork' pattern cutting is necessary to standardize designs to most efficiently utilize varying source materials in appealing designs.

The benefits of upcycling include using waste as a source material, diverting it from landfill, and in doing so reducing carbon emissions and other negative environmental impacts. This creates a cost effective reuse of scarce resources and the embodied energy contained from initial manufacture. Upcycling provides opportunities for further training and education in the fashion and textiles industry. Employment in this sector is currently dominated by retail, with declining provision for training in areas such as manufacturing and entrepreneurship (British Fashion Council 2010; Skillset Textiles 2010). The UK has the chance to fill in skills gaps currently faced by new entrepreneurs with the provision of training within upcycling businesses. Upcycling also supports economic localization, by utilizing locally sourced materials, work force and skills, plus adding to the development of local communities by engaging with the public through activities connected to sustainable consumption, skills sharing and education.

Modular manufacturing, in which operatives are responsible for several processes in a single garment's manufacture, is already in use to varying degrees throughout upcycling businesses in the UK. In combination with locally based home workers, modular manufacturing can allow greater involvement of craftsmanship in the production of high quality upcycled products than in mass manufacturing (Cassidy and Han 2012: 161-162).

Opportunities are presented to develop a UK led fashion upcycling industry, boosting the declining UK garment industry, and setting international standards for sustainable practice. This approach directly addresses the textile waste problem, and offers opportunities for further employment and 
training within the industry. New retail and business opportunities are presented within the preexisting UK textile collection industry and the possibility of establishing a consortium of ethical and upcycling designers within localized areas in order to best utilize resources is also presented. Recommendations on how to best engage individuals and communities with ethical and environmental issues are also expressed in terms accessibility and demand. 


\section{References}

Allwood, Julian M, Soren Ellebaek Laursen, Ceceilia Malvido de Rodriguez, and Nancy M P Bocken. 2006. "Well Dressed? The Present and Future Sustainability of Clothing and Textiles in the United Kingdom". Cambridge: University of Cambridge-Institute for Manufacturing.

Armstrong, Cosette M, and Melody L A LeHew. 2011. "Sustainable Apparel Product Development: In Search of a New Dominant Social Paradigm for the Field Using Sustainable Approaches." Fashion Practice: The Journal of Design Creative Process \& the Fashion Industry 3 (1) (May 1): 29-62.

Aus, Reet. 2011. "Trash to Trend - Using Upcycling in Fashion Design." Doctoral Thesis, Estonian Academy of Arts.

Bartlett, Caroline, lan McGill, and Peter Willis. 2013. "Textiles Flow and Market Development Opportunities in the UK". Vol. 2012.

Braungart, Michael, and William McDonough. 2002. Cradle to Cradle. London: Vintage.

British Fashion Council (2010) The Value of the UK Fashion Industry. London.

Bryman, Alan. 2008. Social Research Methods. $3^{\text {rd }}$ ed. Oxford: OUP Oxford.

Bryman, Alan. 2012. Social Research Methods. $4^{\text {th }}$ ed. Oxford: OUP Oxford.

Burke, Sandra. 2008. Fashion Entrepreneur: Starting Your Own Fashion Business. Dorset: Ringwood.

Carr, Harold, and Barbara Latham. 1994. Carr and Latham's Technology of Clothing Manufacture. $2^{\text {nd }}$ ed. Oxford: Blackwell.

Cassidy, Tracy Diane, and Sara Li-Chou Han. 2012. "Upcycling Fashion for Mass Production." In Sustainable Fashion \& Textiles, edited by Ana Laura Torres and Miguel Angel Gardetti. Sheffield: Greenleaf Publishing.

Dadigamuwage, Geetha Kanchanamala Dissanayake. 2012. "Sustainable and Remanufactured Fashion." PhD Thesis, The University of Manchester.

Dunn, Janet. 2008. "ReFashion ReDunn." Master of Design Thesis, Massey University, Wellington, New Zealand.

Farrant, Laura, Stig Irving Olsen, and Arne Wangel. 2010. "Environmental Benefits from Reusing Clothes." The International Journal of Life Cycle Assessment 15 (7) (May 27): 726-736. 
Fletcher, Kate. 2008. Sustainable Fashion and Textiles: Design Journeys. London: Earthscan.

Flick, Uwe. 2011. Introducing Research Methodology: A Beginner's Guide to Doing a Research Project. London: Sage Publications Ltd.

Fraser, Kim. 2009. "ReDress-ReFashion as a Solution for Clothing (un) Sustainability." Master of Art and Design Thesis, AUT University, Auckland, New Zealand.

Gam, Hae Jin, Huantian Cao, Jaclyn Bennett, Caroline Helmkamp, and Cheryl Farr. 2011. "Application of Design for Disassembly in Men's Jacket: A Study on Sustainable Apparel Design." International Journal of Clothing Science and Technology 23 (2/3): 83-94.

Giaglis, G M. 2001. "A Taxonomy of Business Process Modeling and Information Systems Modeling Techniques." Journal of Flexible Manufacturing Systems 13 (2): 209-228.

Gwilt, Alison. 2011. "Producing Sustainable Fashion: The Points for Positive Intervention by the Fashion Designer." In Shaping Sustainable Fashion, edited by Alison Gwilt and Timo Rissanen. London: Earthscan.

Hansen, Karen Tranberg. 2004. "Helping or Hindering? Controversies around the International Second-Hand Clothing Trade." Anthropology Today 20 (4): 3-9.

Hines, Peter, and Nick Rich. 1997. "The Seven Value Stream Mapping Tools.” International Journal of Operations \& Production Management 17 (1): 46-64.

Jankowicz, A.D. 2000. Business Research Projects. London: International Thomson Business Press.

Jenkyn Jones, Sue. 2005. Fashion Design. Second Edi. London: Laurence King.

Matharu, Gurmit. 2010. What Is Fashion Design? Mies: Rotovision.

McKelvey, Kathryn, and Janine Munslow. 2003. Fashion Design: Process, Innovation and Practice. Oxford: Blackwell Science.

Morley, Nick, Ian McGill, and Caroline Bartlett. 2009. "Maximising Reuse and Recycling of UK Clothing and Textiles EV0421 Technical Report Final Report for Defra." Direct.

Payne, A. 2011. "The Life-Cycle of the Fashion Garment and the Role of Australian Mass Market Designers." The International Journal of Environmental, Cultural, Economic and Social Sustainability, 7(3), pp. 237-246. 
Sinha, Pammi. 2002. "Creativity in Fashion." Journal of Textile Apparel, Technology and Management 2 (4).

http://www.tx.ncsu.edu/jtatm/volume2issue4/articles/sinha/sinha_full_25_02.pdf.

Skillset Textiles. 2010. "What Are the Main Skills Issues and Concerns?" UK Government: Skillset Sector Skills Council. http://www.skillset.org/fashion_and_textiles/industry/article_7631_1.asp.

Thomas, Sue. 2008. "From Green Blur to Ecofashion: Fashioning an Eco-Lexicon." Fashion Theory: The Journal of Dress, Body \& Culture 12 (4): 525-540.

Waste Online. 2010. "Waste Online Textiles Recycling Information Sheet." http://www.wasteonline.org.uk/.

Young, C., C. Jirousek, and S. Ashdown. 2004. "Undesigned: A Study in Sustainable Design of Apparel Using Post-Consumer Recycled Clothing." Clothing and Textiles Research Journal 22 (12) (January 1): 61-68. 